\title{
Social Media in the Constituent Interaction and Mobility: Case Study in the 2017 Jakarta-Indonesia Governor General Election Campaign
}

\author{
Yunila Laras Ismawani \\ Communication Department, BINUS \\ Graduate Program, Master of Strategic \\ Marketing Communications \\ Bina Nusantara University \\ Jakarta, Indonesia \\ yunila.laras@gmail.com
}

\author{
La Mani \\ Communication Department, BINUS \\ Graduate Program, Master of Strategic \\ Marketing Communications \\ Bina Nusantara University \\ Jakarta, Indonesia \\ la.mani@binus.edu
}

\author{
Muhamad Aras \\ Communication Department, BINUS \\ Graduate Program, Master of Strategic \\ Marketing Communications \\ Bina Nusantara University \\ Jakarta, Indonesia \\ maras@binus.edu
}

\begin{abstract}
The use of social media in general election campaign in the third world countries, especially in Indonesia, becomes more common but the relationship between social media existence in political campaign and the final vote result still need to be scrutinized. Therefore, this study aimed to analyse with a systematic and empirical approach of the social media usage (Including Facebook, Twitter, and Instagram) by DKI Jakarta governor candidates for the 2017-2022 period. Based on the observations, we found that each DKI Jakarta governor candidate has had a popular social media accounts in Indonesia, namely Facebook, Twitter, and Instagram. Such media were used to in conducting political campaigns and interacting with their constituents. Based on in-depth analysis of the empirical data showed that the presence of social media in the political campaigns in Indonesia had a strong relationship with the final results of DKI Jakarta governor election. Relationship between the results of the general election and the popularity, participation, and activeness of candidates in using social media were shown not only in the interaction quantity but also in the quality of the political campaign contents. Furthermore, social media popularity of the political parties which supported the candidates allegedly had a relationship with 2017 DKI Jakarta governor election results.
\end{abstract}

Keywords: Waste Recycle; Banking System; Economic Empowerment; Bank Sampah Matahari Madiun

\section{INTRODUCTION}

Before the 20th century, when television and internet had not been yet in widespread use as a medium of information dissemination, print media and radio had become popular media in conveying the message or information, including a political message to the public. At that time, more political campaigns were carried out in the direct speech, radio channel, print media such as newspapers and magazines. Nevertheless at the beginning of the 20th century, the development of television had shifted slightly the existence of print media for political campaigns, especially in developed countries. Television was then able to provide a large effect on the mass public's assessment of a candidate's attractiveness, people's willingness to vote for a candidate, and judgments about a candidate's likelihood of garnering the nomination [1]. Print media, radio, and television were able to maintain their existence in long time so that their role in political campaigns around the world could not be minimized.
Entering the digital era in the 21 st century, internet technology development around the world had brought about significant changes in all aspects of life. Every year the internet usage and users become more increasing along with the breadth of the Internet network infrastructure and convenience in obtaining digital devices. The use of internet and social media in Indonesia had become inseparable part of daily communication. Based on the survey conducted by the Association of Indonesian Internet Service Provider in 2017, the number of internet users in Indonesia had reached 143,26 million or $54,68 \%$ of the total population, an increase of $7,96 \%$ from 2016 [2]. Indonesia had become the fifth largest internet user in the world. According to research conducted by We Are Social and Hootsuite, out of 265,4 million Indonesians, 130 million were active users of social media, with the top positions dominated by Youtube, Facebook, WhatsApp, Instagram, and Line [3]. In the political field, the use of Internet as a new media of political communication and campaign became very popular [4]. Perlmutter [5] identified that online political campaign had been started since 1992 by Bill Clinton who was then followed by political parties, other candidates, and the electoral success teams.

Along with the increasingly social media popularity, political parties and politicians themselves had upgraded their campaign strategy from that originally only based offline, such as the installation of banners, campaign speeches, and the leaflets spread to the public, evolved into the online basis, such as through Facebook, Twitter, Instagram, Youtube, etc. Indonesia with a very diverse and segregated population of islands looked at the existence of social media as an effective means of political communication and election campaign. For example, we took a case study in the 2017 DKI Jakarta governor election. DKI Jakarta was spread into 6 regions, namely North Jakarta, West Jakarta, Central Jakarta, South Jakarta, East Jakarta, and Kepulauan Seribu. DKI Jakarta governor candidates used social media as massive communication channel to socialize themselves and their programs. The question arised whether the existence of online political communication and campaign through social media from candidates, who took a part in the general election, had capability or not to mobilize their constituents so that they met the expected votes and victory of the election.

Aparaschivei [4] conducted research related to the use of social media in the Romania presidential campaign in 2009. 
The results indicated that there were no positive relationship between the real vote result of a president candidates with their political communication strategy through social media. This research was conducted at the time of the Romania presidential election in 2009 which was the first year of social media use for election campaigns in Romania. On the other hand, internet technology development and the use of social media had not been widespread use like nowadays. The candidate presidents were not in a structured way to utilize social media in their political campaigns. Nevertheless along with the rapid use of social media in Indonesia, especially in DKI Jakarta as the capital city of Indonesia, had stimulated the authors to observe the activities and existence of online political communication of DKI Jakarta governor candidates for the 2017-2022 period. This study aimed to find out whether there was relationship between the use of social media in a political communication strategy and the results of final vote that led one of the candidates as the winner in the general election. Focused study was related to posts or political campaigns, a series of strategies, the characteristics of the candidates' social media, and communication mistakes of the candidates on the Facebook, Twitter, and Instagram platform.

\section{LITERATURE REVIEW}

\section{A. Social Media in Democracy}

According to Ward [6], social media is one type of online media that accelerates communication like a conversation, and is different from conventional media that does not allow readers to participate in content creation. The use of social media in democratic process had been carried out by many countries around the world. Such an example of the United States, known as the most influential country in democracy practices and had become a benchmarking state for other countries in the world on communications and political campaigns through online media. The United States had demonstrated the power of social networking for promoting the candidates in the presidential election which ultimately led one of the candidates as the winner [4]. Indonesia which is one of the democracy countries in Southeast Asia, also adopted direct general elections.

Internet users are believed to be new decision makers in the digital world [7]. Through information and interaction exposure that occur on social media, they are expected to be able to make decisions that are more prudent and directed, including political choice decisions in general elections. Political participation of people in social media was also interesting to study, considering their decisions were closely related to the results of the general elections held. The utilization of new media in attracting political participation of voters and relationship of political participation with internet literacy factor showed that many of voters who were also social media users still tend to be apathetic toward politics [8]. Nevertheless the relationship of political participation and internet literacy showed quite high [8]. In addition, a survey conducted on 6.330 young children in Belgia [9] also showed that despite the time they spend on social media very much, they did not follow all sorts of activities and political discussions $(88 \%$ of respondents never read or forwarded emails related to political contents). Furthermore, based on this survey it was known that the use of blogs, reading online news related to politics, and sending emails with political contents could have a positive effect on political participation in the real world. From these studies, candidates and campaign success teams might know the importance of social media in the democratic process and it's influence on online audience's political behaviour.

\section{B. Internet Users and Political Constituents in Indonesia}

Indonesia with the fourth largest population in the world, approximately 3,5\% of the total world population (CIA World Factbook 2018), was the fifth largest internet user in the world. Based on data from a survey conducted by the Association of Indonesian Internet Service Provider (APJII), the number of internet users increased by $795,38 \%$ within 12 years, from 2005 to 2017 .

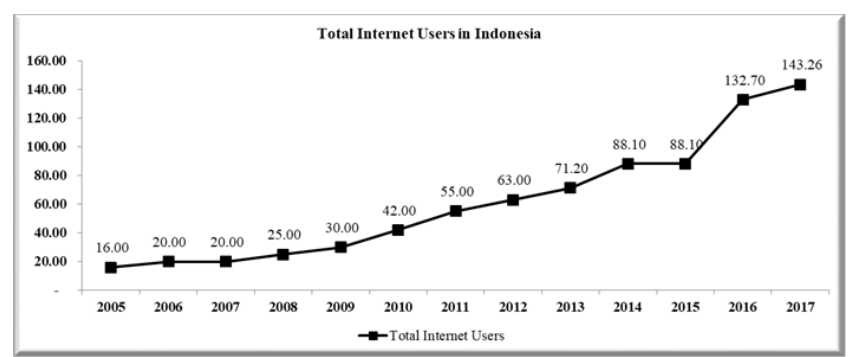

Figure 1. Trend number of internet users in Indonesia for the period 2005-2017.

Source: Indonesian Internet Service Providers Association (APJII) on Kompas.com

Total internet users in Indonesia at the time of this research conducted was 143,26 million people or $54,68 \%$ of the total population in Indonesia with the composition of internet users consisting of $51,43 \%$ men and 48,57\% women [2]. In line with this, development of Facebook, Twitter, Youtube, and Instagram since 2008 had made these social media became very popular in Indonesia with the penetration number of followers as follows:

Table 1. Penetration number of social media followers in Indonesia.

\begin{tabular}{ccr}
\hline $\begin{array}{c}\text { Types of social } \\
\text { media }\end{array}$ & $\begin{array}{c}\text { Number of } \\
\text { followers }\end{array}$ & \% Penetration \\
\hline Facebook & 130 million & $49.64 \%$ \\
Twitter & 46 million & $17.56 \%$ \\
Instagram & 53 million & $20.23 \%$ \\
\hline
\end{tabular}

Source: Internet World Stats and TechCrunch

In the context of general elections, there are two parties directly correlated, the candidate to be elected and the elector (voter). Voters here are often referred to constituents. In terms of general elections, the correlation between internet users and constituents is a relationship that does not directly impact, but have ability to be an indicator of constituent political behaviour. A research [10] concluded that the number of responses to a candidate's tweet compared to other candidates on social media such as Twitter could statistically be used as an indicator of the vote acquisition in general election. In reality, the number of internet users are not always directly proportional to the number of constituents in a country. For example internet users of Indonesia in 2017 amounted to 143,26 million people with potential constituents approximately (internet users aged 18 years to above) was $83,32 \%$ or 119,36 million people [2]. On the other hand, based 
on data from the Domestic Ministry, it was known that the number of constituents in Indonesia was predicted to reach 196,5 million [11]. This showed that there were slices of data which illustrated that not all constituents had access to the internet and likewise that internet users might not necessarily be constituents if they were not quite in accordance with election regulation. In the other hand, possible bias data from internet users might happen because one person could have more than one account in social media. Thus, contradictory and irregularities in predicting public political behaviour in the real world by seeing their behaviour in the online media might largely occur

\section{Political Campaign Through Social Media}

In practice, campaign activities are carried out through electronic media (television and radio), print media (newspapers, magazines, and tabloids), group communication media (exhibitions, seminars, and panel discussions), and outdoor media (posters, banners, and billboards). But along with technology development, campaigns through digital media (social media, websites, e-mail, and chat applications) become more popular that have several advantages, such as:

\section{Improve cost efficiency and campaign time flexibility.}

The cost needed to spread political content through social media is very cheap. In contrast, putting content on newspaper, magazine, television, or radio need to spend more money. Moreover, political campaign through social media has time flexibility beneficial so that the campaign team and candidate can actively promote their programs and visions anytime and anywhere. Besides being able to streamline campaign costs, social media could mobilize fundraisers from sympathizers in the online world, such as in the 2012 DKI Jakarta governor election campaign which sent Joko Widodo and Basuki Tjahaja Purnama to be the winner. They attracted sympathizers through social media and raised funds campaign from selling attributes, such as Jokowi-Ahok's distinctive plaid shirts that were widely marketed by sympathizers and selling ticket of The Lady in the XXI Taman Ismail Marzuki theater. The sale of Jokowi-Ahok's plaid shirt was even targeted to reach Rp. 20 billion which was used for campaign costs and paying the witnesses at the voting place. This concept was also carried out during the 2008 US Presidential election which was an excessive example of how the role of social media as the main campaign tool on the political stage was gaining attention from around the world. Obama's victory was a decisive turning point in the modernization of political campaigns [12]. Obama and his success team succeeded in using the internet and social media in political campaigns to raise funds, organize citizens, and mobilize voters [12].

2. Increase the effectiveness of information dissemination and exchange of ideas.

Social media coverage is very broad and unlimited. Once a message is released then the effect on online audiences could not be stopped. It was as described in the theory of a hypodermic needle or bullet theory initiated by Harold Lasswell in the 1920s. The theory that was born during World War I assumed that the public did not have the power to avoid media influence. In the use of social media, audiences are often faced with a variety of information exposure disseminated by news content owners. The information disseminated could be the real news but sometimes could be the hoaxes in which readers were often immediately trust without comparing the contents first. This phenomenon sometimes is further exacerbated by content viralisation which may cause negative electronic word of mouth (eWOM). Social media users still have a variety of alternative channels to filter news content so that they could avoid the effects of hypodermic needle in political decision making. Like two sides of the blade, dissemination of information through social media could be an advantage and disadvantage. If the work program and the positive image of the candidate were spread, the positive effect (eWOM) would happen. On the contrary, negative and black campaigns could have an impact on the killing of candidate's character.

Effectiveness, efficiency, and flexibility become an attraction in the use of social media for candidates and their success teams in conducting political campaigns. Unfortunately, Asp and Esaiasson [13] stated that the shift in communication strategies to social media actually had a large negative impact, especially for the mass community. This was because the political world as seen in the mass media was becoming increasingly full of drama. The public as media consumers saw the political world as seen and displayed in the media. For example, every case is deliberately shared to create a black campaign from political opponents could have an impact on the decreasing number of voters as McChesney [14] had stated which could lead to slow depoliticization process against the public. Symptoms of depoliticization was marked from public apathy about the political issues to the drop in number of voter turn-out in elections.

Internet and social media literacy in Indonesia are still distributed unevenly therefore the use of social media in political campaign needs to consider the condition of its constituents. According to survey conducted by the Association of Indonesian Internet Service Provider (APJII), it was known that penetration of internet users by geography as follows:

Table 2. Penetration of internet users by geography.

\begin{tabular}{lr}
\hline Regional geography & Internet users penetration \\
\hline Jawa & $57,70 \%$ \\
Sumatera & $19,09 \%$ \\
Kalimantan & $7,97 \%$ \\
Sulawesi & $6,73 \%$ \\
Bali - Nusa Tenggara & $5,63 \%$ \\
Maluku - Papua & $2,49 \%$ \\
\hline
\end{tabular}

Source: Indonesian Internet Service Providers Association (APJII) on Kompas.com

This uneven literacy should not complicate the democratic process and political campaigns for society because essentially democracy is the government of the people, by the people, and for the people. Community inability to use social media had been studied by a study and showed that instead of increasing citizen political participation on a broad scale, the internet actually played a role in sharpening fragmentation and isolating citizens. Therefore political campaigns in developing countries such as Indonesia should still use a combination of conventional media and online media to accommodate all society. Furthermore, political campaign through social media could be very effective as long as an ethical political awareness of online media users existed and protected by the 
rule of law regarding Electronic Information and Transactions regulation [15].

\section{Political Parties in General Elections in Indonesia}

General elections in Indonesia began in 1955 and up to 2014 Indonesia had executed eleven times of presidential election. Generally, presidential elections in Indonesia are held every five years but there was a period in which Indonesia did not execute elections during 16 years, that was in the general election in 1971 after the recess from 1955. In the year of 1999, after the end of Orde Baru, the election was held intermittent only 2 years of the previous general election in 1997. The end of the Orde Baru regime was marked by the fall of President Soeharto, who had led Indonesia for almost 32 years. This signaled the rise of a new democracy in Indonesia and was known as the Reformation era. During Orde Lama until the beginning of the Reformation era, election in Indonesia were intended to elect legislative members, but after the fourth amendment to the UUD 1945 in 2002, the presidential elections originally voted by the People's Consultative Assembly (MPR) were agreed to be carried out directly by Indonesian citizen. Furthermore, based on UU No. $22 / 2007$, the election of regional head was also agreed to be directly elected by the people.

Along with the development of political parties in Indonesia, from 1955 until now, there were a lot of changes in the number of political parties which is participating in general elections in Indonesia as shown in Table 3.

Table 3: Trend number of election contesting political parties in Indonesia.

\begin{tabular}{cr}
\hline Period & $\begin{array}{c}\text { Number of election contesting political } \\
\text { parties }\end{array}$ \\
\hline 1955 & 172 parties \\
1971 & 10 parties \\
$1977-1997$ & 3 parties \\
1999 & 48 parties \\
2004 & 24 parties \\
2009 & 38 parties and 6 Aceh local parties \\
2014 & 12 parties and 3 Aceh local parties \\
2019 & \\
\hline
\end{tabular}

Source: https://id.m.wikipedia.org

As a political organization, parties tend to struggle the interests of their members especially and society generally as well as maintain the integrity of the state. In order to achieve these goals, a strategy is needed to campaign the party's vision, mission, and political direction through various media (multimedia), one of which is social media. Number of political parties official account followers in social media up to the time when this research was conducted could be quantified as follows:

Table 4. Number of social media followers of political parties participating in 2019 elections.

\section{Political Party Facebook Twitter Instagram}

\begin{tabular}{llll}
\hline Partai Demokrasi & & 174.000 & 66.200 \\
Indonesia & 1.569 .551 & & \\
Perjuangan (PDI-P) & & &
\end{tabular}

\begin{tabular}{|c|c|c|c|}
\hline Partai Golongan & 55.958 & 95.000 & 10.000 \\
\hline \multicolumn{4}{|l|}{ Karya (Golkar) } \\
\hline Partai Nasional & 50.348 & 64.300 & 10.900 \\
\hline \multicolumn{4}{|l|}{ Demokrat (Nasdem) } \\
\hline Partai Persatuan & 279.467 & 18.200 & 27.000 \\
\hline \multicolumn{4}{|l|}{ Indonesia (Perindo) } \\
\hline Partai Berkarya & 4.105 & 28.100 & 13.500 \\
\hline Partai Demokrat & 191.221 & 72.400 & 15.600 \\
\hline Partai Gerakan & 3.620 .574 & 348.000 & 204.000 \\
\hline \multicolumn{4}{|l|}{$\begin{array}{l}\text { Indonesia } \\
\text { (Gerindra) }\end{array}$} \\
\hline Partai Hati Nurani & 527.143 & 20.000 & 763 \\
\hline \multicolumn{4}{|l|}{ Rakyat (Hanura) } \\
\hline Partai Gerakan & 1.212 & 357 & 2.496 \\
\hline \multicolumn{4}{|l|}{$\begin{array}{l}\text { Perubahan Indonesia } \\
\text { (Garuda) }\end{array}$} \\
\hline Partai Amanat & 174.334 & 29.400 & 15.900 \\
\hline \multicolumn{4}{|l|}{ Nasional (PAN) } \\
\hline Partai Kebangkitan & 48.623 & 76.300 & 22.200 \\
\hline \multicolumn{4}{|l|}{ Bangsa (PKB) } \\
\hline Partai Keadilan & 434.601 & 249.000 & 69.900 \\
\hline \multicolumn{4}{|l|}{ Sejahtera (PKS) } \\
\hline Partai Persatuan & 250.535 & 48.400 & 20.000 \\
\hline \multicolumn{4}{|l|}{ Pembangunan (PPP) } \\
\hline Partai Solidaritas & 2.085 .454 & 69.300 & 70.200 \\
\hline Indonesia (PSI) & & & \\
\hline
\end{tabular}

Source: Official accounts of each political party

Social media could be used to develop political marketing strategies for politicians in showing their policies, figures, parties, and images [16] and formulated political branding like what was done by Jokowi-Ahok during the 2012 DKI Jakarta governor election campaign [17]. Political campaign by Jokowi through Twitter had shown the attitude of a politician who would determine the popularity of himself and his supporting party (Partai Demokrasi Indonesia Perjuangan). The greater the political party's support for candidates, the greater the potential for votes from election bases.

\section{METHODS}

This study aimed to examine and analyse the use of social media by candidates who took part in general elections with case study in the 2017 DKI Jakarta governor election. This study focused on all posts related to communication or political campaign, a series of strategies, social media characteristics, and communication errors made by candidates on the Facebook, Twitter and Instagram platforms. DKI Jakarta governor candidates to be analysed were consisted of three political figures, namely Agus Harimurti Yudhoyono (AHY) from the coalition of Partai Demokrat-PAN-PKBPPP, Basuki Tjahaja Purnama (Ahok) from the coalition of PDIP-Golkar-Nasdem-Hanura, and Anies Baswedan (Anies) from the Gerindra-PKS coalition.

The research methodology used in this study was data observation and analysis with systematic and empirical approach of the social media activities and usage by DKI Jakarta governor candidates on three different platforms (Facebook, Twitter, and Instagram). This method is relevant to research because the object of the research relates to human behaviour, the respondents observed are not many, and the observed phenomena are measured so that they can be compared. 
Observation conducted during this research used some indicators that described the candidate's existence and activities during political campaign. Social media indicators used in this study were divided as follows:

- Observation indicators on Facebook: number of friends, like, posts, photos, videos, and groups.

- Observation indicators on Twitter: number of followers, following, like, and tweets.

- Observation indicators on Instagram: number of followers, following, posts, and hashtags of candidate names.

From these indicators, the observation results were systematically and deeply analysed, then were compared to the actual election results. Therefore we could conclude and summarize the result of this research.

\section{RESULTS}

Based on observations through social media platforms, was known that three candidates of DKI Jakarta governor 2017-2022 period have had popular social media accounts in Indonesia (Facebook, Twitter, and Instagram) with the number of followers were more increasing day by day. All candidates accounts had verification badge symbol on their social media which meant that the account was genuine, trusted, and had a good account management. From the indicators that had been determined in this study, the researcher divided the data observation and analysis into three different sections (Facebook, Twitter, and Instagram).

\section{A. Facebook}

From the number of friends on Facebook, Basuki Tjahaja Purnama hold the first rank since the first campaign period (1,22 million) and up to the second round, the number of friends were getting more increasing that reached more than doubled (2,59 million) until today. The second rank was Anies Baswedan (619 thousand) with an average addition of 150 accounts per day during the campaign period and until now had reached 1,21 million. Meanwhile Agus Harimurti Yudhoyono was in the third position with total friends during the first round campaign reached 52.000s and at the time of this research, the number only reached 179 thousand and were still the lowest compared to other candidates. In line with the number of friends on Facebook, the number of Like Basuki Tjahaja Purnama was the highest with 2,55 million Likes, followed by Anies Baswedan (1,18 million) in the second rank, and the last rank was held by Agus Harimurti Yudhoyono with 174 thousand Likes.

Throughout the pre-campaign and campaign in 2016 until the beginning of 2017, the number of posts on Facebook were most published by Anies Baswedan, made him in the first rank with 192 posts. In the second round until the completion of DKI Jakarta governor election in 2017, the number Anies Baswedan posts were more increasing ( 289 posts) which put him in the first rank with the highest number of posts on Facebook. Anies Baswedan's posts were much related to the work program of $0 \%$ Home Down Payment, activity exploration to various places in Jakarta, and the relevant confirmation tweet evil against him. In the second rank, there was Basuki Tjahaja Purnama with 170 posts during a precampaign and the campaign in 2016 then 265 posts in the campaign and post-campaign in 2017. Posts of Basuki Tjahaja Purnama were more about his activities as DKI Jakarta governor and his success achieved during his leadership. In the third rank, there was Agus Harimurti Yudhoyono with 92 posts during the pre-campaign period and 93 posts during the campaign period. The posts by Agus Harimurti Yudhoyono was more about his effort in building image to the community as he had just involved in politics after leaving the military unit of the Republic of Indonesia.

The number of photos uploaded by each candidate was quite competitive with a slight difference. Basuki Tjahaja Purnama (102 photos) had 3 more photos than Anies Baswedan (99 photos) and Agus Harimurti Yudhoyono uploaded 91 photos in the pre-campaign and 2016 campaign. Conditions changed slightly during the campaign period in 2017 in which Anies Baswedan was in the first rank with 100 photos, the second rank was Basuki Tjahaja Purnama with 96 photos, and the third rank was Agus Harimurti Yudhoyono with 91 photos. The photos uploaded by Anies Baswedan was mostly related to Anies track record which set up like a series of photos starting from the order of 1 to 40 photos and related to 23 Anies work appointments. Meanwhile, Basuki Tjahaja Purnama uploaded a lot of photos with DKI Jakarta people in every work visit and Agus Harimurti Yudhoyono uploaded more photos about his family and his campaign speech.

In line with the number of photos uploaded to Facebook, the first rank in terms of the videos uploaded was achieved by Basuki Tjahaja Purnama with 53 videos during the precampaign and 2016 campaign, followed by Anies Baswedan with 27 videos, and finally Agus Harimurti Yudhoyono with 7 videos. During the 2017 campaign period, the rank experienced a shift in the second and third ranks, in which Basuki Tjahaja Purnama (45 videos) stayed in the first rank, Agus Harimurti Yudhoyono (37 videos) was in the second rank, and the third rank was Anies Baswedan (3 videos). Regarding the number of active groups in Facebook's fanpage of each candidate, Agus Harimurti Yudhoyono had more groups than the other two candidates (47 groups) while Basuki Tjahaja Purnama and Anies Baswedan had 41 and 40 groups respectively. However, not all groups were created to support the candidates. For example in the Facebook of Basuki Tjahaja Purnama, there were at least three groups who were contra with the figure of Basuki Tjahaja Purnama as DKI Jakarta governor candidate.

Table 5. Candidates activity on Facebook of 2016 precampaign and campaign.

\begin{tabular}{lrrrr}
\hline Candidates & $\begin{array}{r}\text { Number } \\
\text { of friends }\end{array}$ & $\begin{array}{r}\text { Number } \\
\text { of posts }\end{array}$ & $\begin{array}{r}\text { Number } \\
\text { of } \\
\text { photos }\end{array}$ & $\begin{array}{r}\text { Number } \\
\text { of } \\
\text { videos }\end{array}$ \\
\hline $\begin{array}{l}\text { Agus } \\
\text { Harimurti }\end{array}$ & 52.000 & 92 & 91 & 7 \\
$\begin{array}{l}\text { Y. } \\
\text { Basuki }\end{array}$ & 1.224 .000 & 170 & 102 & 53 \\
$\begin{array}{l}\text { Tjahaja P. } \\
\text { Anies } \\
\text { Baswedan }\end{array}$ & 619.043 & 192 & 99 & 27 \\
\hline
\end{tabular}

Source: Observation results on each candidate's official account

With a great number of friends on Facebook, Basuki Tjahaja Purnama who was a defense governor of DKI Jakarta, was a candidate with big fans. However, the number of very intense posts from Anies Baswedan (44\% of all candidate 
posts) and photo uploads that attracted online audiences could change the winning position on this platform even though the number of videos uploaded by Basuki Tjahaja Purnama was still superior $(57 \%$ of total video) compared to Anies Baswedan (17\%). Content management of both candidates on the Facebook platform was also very good in which their account administrators regularly and neatly uploaded the campaign contents. Therefore it was boosting audiences awareness to the campaign. On the other hand, Agus Harimurti Yudhoyono was less active on Facebook with 185 posts uploaded during the 2016 and 2017 campaigns, but the figure of Agus Harimurti Yudhoyono as a candidate for young leaders made him got a lot of fans. There were at least 47 Facebook groups created to support Agus Harimurti Yudhoyono and these groups were very popular with different members and activeness levels. Therefore, according to level of activity and popularity reason, Basuki Tjahaja Purnama could be regarded as the winner on the Facebook platform, accounted for $40 \%$ of the total posts, $57 \%$ of the total video, $34 \%$ of the total picture, and $65 \%$ from total friendship.

Table 6. Candidates activity on Facebook of 2017 campaign and post campaign.

\begin{tabular}{lrrrr}
\hline Candidates & $\begin{array}{c}\text { Number } \\
\text { of friends }\end{array}$ & $\begin{array}{r}\text { Number } \\
\text { of posts }\end{array}$ & $\begin{array}{r}\text { Number } \\
\text { of } \\
\text { photos }\end{array}$ & $\begin{array}{r}\text { Number } \\
\text { of } \\
\text { videos }\end{array}$ \\
\hline $\begin{array}{l}\text { Agus } \\
\text { Harimurti }\end{array}$ & 179.065 & 93 & 99 & 37 \\
$\begin{array}{l}\text { Y. } \\
\text { Basuki }\end{array}$ & 2.591 .920 & 265 & 96 & 45 \\
$\begin{array}{l}\text { Tjahaja P. } \\
\text { Anies } \\
\text { Baswedan }\end{array}$ & 1.214 .031 & 289 & 100 & 3 \\
\hline
\end{tabular}

Source: Observation results on each candidate's official account

The more friends on Facebook, the greater the potential for a post in view, in like, in comment, and even in reshare. This could have both good impact and bad impact according to the content published. The successful achievement of the defense governor, Basuki Tjahaja Purnama, which was often uploaded in Facebook could quickly spread that effect positive e-WOM during the campaign. However, the blasphemy of religion issue occurred by Basuki Tjahaja Purnama whose video uploaded directly to Facebook became an adverse effect on his image and electability. Communication errors related to the quotation of Surat Al Maidah verse 51 deliberately edited by irresponsible party could be used by his political opponents to carry out black campaigns which led to slander and chaos in society. The voluminous demonstrations that demanded to imprison Basuki Tjahaja Purnama increasingly made the political heat in DKI Jakarta. The culmination of this issue was on the final result of general election in the second round in which Basuki Tjahaja Purnama had to accept the defeat due to the issue of SARA which overshadows the general election. Religion and political issues had been mixed so that people were sedated by media exposure whose truth had not been proven in court.

\section{B. Twitter}

Slightly different from Facebook, the number of followers of Basuki Tjahaja Purnama was the highest with 6,38 million (75\% of total followers ) during the campaign period and increased steadily until today has reached more than 7,87 million. The number of the second highest followers was reached by Anies Baswedan with 1,24 million followers in the campaign period and currently has doubled (2,26 million). Meanwhile Agus Harimurti Yudhoyono was still in the bottom position compared to other candidates, with 291 thousand followers during the campaign and in the time of this study held, the number of followers were not more than 308 thousand.

Beside the number of followers, number of following which indicated the involvement and interest of DKI Jakarta governor candidates also need to be assessed. Amount of followers could indicate the number of sympathetic, but the number of following could describe the concerns of candidate about issues or specific figures and allowed candidates to interact with more followers in Twitter. Based on the number of following, Anies Baswedan had the most following number to other accounts (642 following) while the second was Agus Harimurti Yudhoyono with 146 following. Basuki Tjahaja Purnama with the greatest number of followers, in fact only had 52 following on Twitter. Therefore, in the case of openness to interact with online audiences, Anies Baswedan had a higher openness than the other two candidates.

In terms of the number of Like on Twitter, Anies Baswedan was more superior than two other candidates with 11.300 Like much left Agus Harimurti Yudhoyono with 271 Like, and Basuki Tjahaja Purnama with only 41 Like. This condition is inversely proportional to the number of Like on Facebook that made Basuki Tjahaja Purnama was in the first rank.

Based on the number of tweets of each candidate during the campaign period, Anies Baswedan was in the first ranked with 10.200 tweets $(72,34 \%)$. In the second rank was achieved by Basuki Tjahaja Purnama with 2.449 tweets $(17,37 \%)$, and the third rank was held by Agus Harimurti Yudhoyono with 1.452 tweets (10,29\%). Based on research conducted from September 23rd to October 9th 2016 by Provetic that the conversation on Twitter was dominated by Basuki Tjahaja Purnama [18], which was $83 \%$ of the total conversations on Twitter, followed in the second position by Agus Harimurti Yudhoyono (12\%), and Anies Baswedan (6\%). Discussions and talks about Basuki Tjahaja Purnama were more related to negative sentiments about his statement quoting the Al-Quran Surat Al-Maidah in his site visit to Kepulauan Seribu. Meanwhile the positive sentiment was highest in the discussion about Agus Harimurti Yudhoyono who had just involved in the politics. Agus Harimurti Yudhoyono was considered as a young person who was polite, cool, and diciplined. Conversations at Tweeter related to Anies Baswedan had not experienced a significant increase in the initial period of the 2016 campaign and less discussed about his participation in DKI Jakarta governor election. However, in the second round of campaign, the number of tweets by Anies Baswedan continued to increase even up to this research has reached 11.300 tweets while Basuki Tjahaja Purnama had no more than 2.605 tweets, and Agus Harimurti Yudhoyono tweeted 1.458. Although the number of his followers was only one-third of Basuki Tjahaja Purnama, yet another positive indicator of the number of posts ( $74 \%$ of total tweets), the number of Like (97\% of total Like), and the number of following ( $76 \%$ of the total following) that 
reflected the attitude of openness from Anies Baswedan made him right to be awarded as the winner on Twitter platform.

\section{Instagram}

Much different from previous social media, number of Agus Harimurti Yudhoyono's Insatgram followers during the first round campaign was the largest (1,80 million) compared to other candidates. In the second rank was obtained by Basuki Tjahaja Purnama (1,60 million) and the third rank was achieved by Anies Baswedan with 189 thousand followers. The dramatical changes happened along the campaign period in which the increase of followers number of Basuki Tjahaja Purnama soared to more than 3 million. Meanwhile Agus Harimurti Yudhoyono was in the second rank with current followers 2,6 million and the third rank with 1,3 million followers achieved by Anies Baswedan.

The most number of followings was owned by Anies Baswedan with 128 following, the second was Agus Harimurti Yudhoyono with 46 following, and the third was Basuki Tjahaja Purnama with 4 following. In terms of number of posts on Instagram during the campaign period until the research conducted, the highest number of posts was held by Agus Harimurti Yudhoyono with 695 posts, followed by Basuki Tjahaja Purnama in the second rank (622), and Anies Baswedan in the third rank (392).

In addition to the number of posts by candidates, number of hashtags of each candidate also needed to be analysed because they were related to public interest in social media toward the candidates. For Anies baswedan's hash tag posted up to 750 thousand which made Anies Baswedan in the first rank, while Ahok hashtag posted as many as 669 thousand, and Ahy's hash tag made 47 thousand posts.

Table 7. Candidates activity on Instagram during campaign period.

\begin{tabular}{lcrrr}
\hline $\begin{array}{l}\text { Candidat } \\
\text { es }\end{array}$ & Hashtag & $\begin{array}{r}\text { Number } \\
\text { of } \\
\text { follower } \\
\text { s }\end{array}$ & $\begin{array}{r}\text { Numb } \\
\text { er of } \\
\text { tweets }\end{array}$ & $\begin{array}{r}\text { Numb } \\
\text { er of } \\
\text { hashta } \\
\text { g }\end{array}$ \\
\hline $\begin{array}{l}\text { Agus } \\
\text { Harimurt }\end{array}$ & \#AHY & 1.800 .0 & 695 & 47.628 \\
$\begin{array}{l}\text { i Y. } \\
\text { Basuki }\end{array}$ & \#Ahok & 1.600 .0 & 622 & 669.94 \\
$\begin{array}{l}\text { Tjahaja } \\
\begin{array}{l}\text { P. } \\
\text { Anies }\end{array}\end{array}$ & & 00 & & 0 \\
$\begin{array}{l}\text { Basweda } \\
\text { n }\end{array}$ & $\begin{array}{c}\text { \#Aniesbaswed } \\
\text { an }\end{array}$ & 189.000 & 392 & 750.42 \\
\hline
\end{tabular}

Source: Observations on each candidate's official account and Funlitic survey

Agus Harimurti Yudhoyono's activity on the Instagram platform which was bigger than the other two candidates during the campaign period showed that the characteristics of Instagram's social media were initially used more by the younger generation, while Facebook and Twitter had entered the mature era for communication on social media. However, the conditions could always change in which Instagram's popularity had led old generation candidates use this platform as well as to garner sympathizers and wider network of constituents.
The number of followers from Agus Harimurti Yudhoyono in early 2016 pre campaigns and campaigns was more than the other two candidates with $50 \%$ of the total followers. But in the 2017 campaign period, the conditions changed instantly where the number of followers of Basuki Tjahaja Purnama pursued to reach 3 million to date. The number of Instagram followers of Anies Baswedan was the lowest (19\% of total followers) but Anies's openness as reflected in the number of following was superior to the other candidates ( $72 \%$ of the total following). In addition, the public concern for Anies Baswedan's hashtag was very large (51\% of the total public posts). However the highest number of posts during campaign period was made by Agus Harimurti Yudhoyono with $41 \%$ of total posts. Thus based on the Instagram indicators, three candidates had balanced strength. The strength of popularity laid with Basuki Tjahaja Purnama, the strength of support laid with Anies Baswedan, and the strength of activeness laid with Agus Harimurti Yudhoyono. Although there were no dominated strength by one candidate in Instagram platform, Anies Baswedan could be seeded as the winner in this platform because of the amount of support strength from instagram users.

\section{DISCUSSIONS}

High enthusiasm of online audiences towards political issues made a new atmosphere in democracy of Indonesia. This enthusiasm could be seen from the number of friends or followers of each candidate in which more than 20 million Indonesian online audiences had participated in the democratic process on social media. Likewise, DKI Jakarta governor candidates had campaigned through social media by actively posting 20 thousand contents, 600 photos, and 200 videos. The campaign strategy of each DKI Jakarta governor candidate had a difference that made uniqueness. Agus Harimurti Yudhoyono who was the youngest candidate had an image as a polite, cool, and disciplined young person because he was a former member of the military of the Republic of Indonesia. He wanted to strengthen his image as a younger generation that was ready to lead and respected. Agus Harimurti Yudhoyono's posts displayed harmony in the family, closeness to its military, and political campaign speech. The intense platform used was Instagram with photo and captions. The only communication error that became viral from the figure of Agus Harimurti Yudhoyono was his denial of political debate invitations from several television stations. His absences in the several times in the political debate caused ridicule and reduced the level of public trust, especially young voters. In contrast to Agus Harimurti Yudhoyono, DKI Jakarta's defense governor was figure from the old generation who still used Facebook to conduct political campaigns more intensively. It was evident from the number of posts uploaded that much related to work achievement, site activities, and an invitation to continue the work program which had been running. Unfortunately, the SARA issues that became very viral made his political image damaged. He was considered to be demeaning to Muslims and as a result Basuki Tjahaja Purnama had to accept the defeat in the second round in which there was a shift of support from Basuki Tjahaja Purnama supporters to Anies Baswedan due to being affected by this issue. In addition, there was sound support from Agus Harimurti Yudhoyono's supporters to Anies Baswedan. Anies Baswedan was considered to be the right figure for most residents of DKI Jakarta because they had similarities in 
political and religious views. The popularity and activeness of Anies Baswedan on social media could be seen primarily on Twitter in which the number of posts were very much related to Anies Baswedan's track record, work appointments, clarification of Anies Baswedan over the black campaign that attacked him. Anies Baswedan's communication error on social media was hardly found so this became a political advantage for him. He was also known as a person who was intelligent, wise, and polite in speaking. This image was also beneficial for him when arguing with the defense governor who was known as an assertive person.

Supporting political parties from each candidate also had social media that needs to be observed, especially regarding their popularity. Although Anies Baswedan was only supported by two political parties (Gerindra and PKS), the number of followers of both parties were very large and the highest among the number of followers of other political parties, with 4,1 million on Facebook, 597 thousand on Twitter, and 274 thousand on Instagram. The PDIP-GolkarNasdem-Hanura coalition which supported Basuki Tjahaja Purnama was in the second rank in terms of the number of followers on social media, which was 2,2 million on Facebook, 353 thousand on Twitter, and 88 thousand on Instagram. While the Democratic-PAN-PKB-PPP coalition which supported Agus Harimurti Yudhoyono had the lowest number of social media followers, with 664 thousand on Facebook, 227 thousand on Twitter, and 74 thousand on Instagram. From the data derived, it was known that there was a positive correlation between the number of followers of political parties on social media and the results of the vote in the general election which led the candidate as the winner. This was possible because number of followers could become a power base that could generate support for candidates who were promoted.

\section{CONCLUSIONS}

DKI Jakarta 2017 election had been held in two rounds. The first round with a total vote of $42,99 \%$ was awarded for Basuki Tjahaja Purnama that made him in the first place, followed by Anies Baswedan in the second place with $39,95 \%$, and $17,06 \%$ for Agus Harimurti Yudhoyono in the third place. According to PKPU No. 6/2016, if the votes for DKI Jakarta regional head candidates are not more than 50\%, then the second round election must be conducted. Therefore the second round held on April 19, 2017 only took two pairs of candidates with the highest votes. For these vote result, if we compare them with the advantages of each candidate on social media platforms, there was a strong positive correlation between the excellence on social media and actual winnings. The strength of followers and friends of Basuki Tjahaja Purnama, as much as $63 \%$ of the total followers on all three social media platforms, made him very popular which could lead the mobility of its constituents in the real world. Furthermore, level of activity and popularity of candidates contributed to political public awareness and election decision.

The activity of an independent (non-party) candidate on social media also needed to be managed well because if a candidate acted incorrectly, it could lead to unexpected results [4]. This was consistent with the conditions that occured in the second round election in which a candidate's communication errors could be a negative issue on social media which results in mushrooming hoax content and sensitive news to bring down political opponents, which in turn mobilized constituents to immediately change their political choices. On the other hand, supports from public through the social media and massive political campaigns from political parties's social media accounts contributed to candidate election winning.

From this study, we could also find that the management of social media, both individually owned by political candidates and managed by the campaign team had to pay attention not only to the quantity of content posted, photos, and videos uploaded but also the quality of each post. The quality included moral norms, grammar, display layout, contents, image posting, and attitude. Social media could be both friends and opponents to their owners, especially accounts owned by politicians with a large number of followers. The challenge was how to utilize the social media platform in effective political campaign, therefore social media had an impact on the general election result.

\section{REFERENCES}

[1] Ross M H 1992 Television news and candidate fortunes in presidential nomination campaigns: the case of 1984 American Politics Quarterly 20(1) 69-98

[2] Setiawan S R D and Ika A 2018 Tahun 2017, pengguna internet di Indonesia mencapai 143,26 juta orang Kompas Retrieved from https://ekonomi.kompas.com/read/2018/02/19/16111512 6

[3] Bohang F K and Wahyudi R 2018 Berapa jumlah pengguna internet Indonesia? Kompas retrieved from https://tekno.kompas.com/read/2018/02/22/16453177

[4] Aparaschivei P A 2011 The use of new media in electoral campaigns: Analysis on the use of blogs, Facebook, Twitter and YouTube in the 2009 Romanian presidential campaign Journal of Media Research 4(2) 39-60

[5] Perlmutter D D 2008 Blogwars (Oxford: Oxford University Press on Demand)

[6] Kirtis A K and Karahan F 2011 To be or not to be in social media arena as the most cost-efficient marketing strategy after the global recession Procedia-Social and Behavioral Sciences 24 260-268

[7] Van Dijck J 2009 Users like you? Theorizing agency in user-generated content Media, Culture \& Society 31(1) $41-58$

[8] Mudjiyanto B 2012 Literasi internet dan partisipasi politik masyarakat pemilih dalam aktifitas pemanfaatan media baru Jurnal Studi Komunikasi dan Media 16(1) 115

[9] Quintelier E and Vissers S 2008 The effect of Internet use on political participation: An analysis of survey results for 16-year-olds in Belgium Social Science Computer Review 26(4) 411-427

[10] DiGrazia J, McKelvey K, Bollen J, and Rojas F 2013 More tweets, more votes: Social media as a quantitative indicator of political behavior PloS One 8(11) e79449

[11] Koran Sindo 2017 Jumlah pemilih Pemilu 2019 mencapai 196,5 juta orang Sindo News retrieved from https://nasional.sindonews.com/read/1266242/12

[12] Utomo W P 2013 Menimbang media sosial dalam marketing politik di Indonesia: Belajar dari Jokowi-Ahok di Pilkada DKI Jakarta 2012 Jurnal Ilmu Sosial dan Ilmu Politik 17(1) 67-84

[13] Asp K and Esaiasson P 1996 The modernization of Swedish campaign: Individualization, professionalization, and medialization Politics, Media, and modern democracy: An international study of innovations in electoral campaigning and their consequences ed D Swanson and P Mancini (Westport: Praeger) pp 73-90 
[14] McChesney R W 2015 Rich media, poor democracy: Communication politics in dubious times (New York: The New Press)

[15] Hameed S S 2007 Internet deployment in the 2004 Indonesian presidential elections The Internet and national elections: A comparative study of Web campaigning ed R Kluver, N W Jankowski, K A Foot, and S M Schneider (London: Routledge) pp 194-209

[16] Juditha C 2014 Political marketing dan media sosial (Studi political marketing Capres RI 2014 melalui
Facebook Jurnal Studi Komunikasi dan Media 19(2) 225241

[17] Sandra L J 2013 Political branding Jokowi selama masa kampanye Pemilu Gubernur DKI Jakarta 2012 di media sosial Twitter Jurnal E-komunikasi 1(2) retrieved from http://publication.petra.ac.id/index.php/ilmukomunikasi/article/view/912

[18] Yulika N C 2016 Siapa cagub DKI yang kuasai Facebook, Twitter, dan Instagram Liputan 6 retrieved from https://m.liputan6.com/pilkada/read/2626965 